\title{
Les Sogdiens en Chine, Paris, 2005, 444 pp. +20 pl. couleurs h.-t., index. (École Française d'Extrême- Orient, Etudes thématiques, 17)
}

\section{Frantz Grenet}

\section{(2) OpenEdition}

Journals

Édition électronique

URL : http://journals.openedition.org/abstractairanica/14772

DOI : 10.4000/abstractairanica. 14772

ISSN : 1961-960X

Éditeur :

CNRS (UMR 7528 Mondes iraniens et indiens), Éditions de l'IFRI

\section{Édition imprimée}

Date de publication : 15 mai 2007

ISSN : 0240-8910

\section{Référence électronique}

Frantz Grenet, « Les Sogdiens en Chine, Paris, 2005, 444 pp. + 20 pl. couleurs h.-t., index. (École

Française d'Extrême-Orient, Etudes thématiques, 17) », Abstracta Iranica [En ligne], Volume 28 | 2007,

document 55, mis en ligne le 18 septembre 2007, consulté le 25 septembre 2020. URL : http:// journals.openedition.org/abstractairanica/14772; DOI : https://doi.org/10.4000/abstractairanica. 14772

Ce document a été généré automatiquement le 25 septembre 2020.

Tous droits réservés 


\title{
Les Sogdiens en Chine, Paris, 2005, 444 pp. +20 pl. couleurs h.-t., index. (École Française d'Extrême-Orient, Etudes thématiques, 17)
}

\author{
Frantz Grenet
}

1 Ce volume, introduit par É. de la Vaissière («Les Sogdiens en Chine: quelques réflexions de méthode »), réunit 21 contributions extraites d'un colloque tenu en avril 2004 à Pékin, publiées en français ou en anglais. Un tiers sont dues à des philologues et archéologues chinois.

2 La principale découverte nouvelle dont il a été fait état au colloque est celle du sarcophage du sabao sogdien Wirkak (en chinois Shi Jun, « le seigneur keshien »), mort à Xi'an en 579. Les reliefs qui le décorent offrent l'iconographie la plus riche et la plus variée dans tout ce qui était connu jusqu'à présent sur les tombaux des émigrés sogdiens en Chine du Nord, et, cas unique, il comporte deux épitaphes, l'une en sogdien et l'autre en chinois. Voir ici : Yang Junkai, « Carvings on the stone outer coffin of Lord Shi of the Northern Zhou » (dessins de toutes les faces, couverture photographique sur les pl. h.-t. 1-7) ; Sun Fuxi, «Investigations on the Chinese version of the Sino-Sogdian bilingual inscription of the tomb of Lord Shi "; Yu. Yoshida, "The Sogdian version of the new Xi'an inscription ». Le parallèle entre les deux inscriptions démontre l'équivalence entre sogd. srtp' $w$ « chef de caravane » et chin. sabao, titre administratif désignant un chef de communauté étrangère; la version sogdienne fournit plusieurs

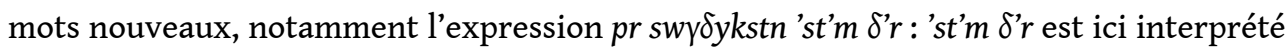
"grandee» (d'après le sanscrit sthāma "pouvoir »), mais N. Sims-Williams dont l'opinion est aussi citée suggère d'amender en 'st'n $\delta$ ' $r$ "propriétaire d'un domaine ";

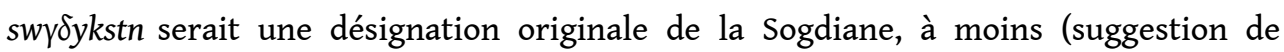
P. Lur'e) qu'il ne s'agisse de la colonie sogdienne de Kachān (Guzang), ville où le défunt avait d'abord résidé. Pour l'interprétation des scènes religieuses, l'information donnée dans ces articles est à compléter par : F. Grenet, P. Riboud, Yang Junkai, « Zoroastrian 
scenes on a newly discovered Sogdian tomb in Xi'an, Northern China » (St. Ir., 33, 2004, pp. 273-284); É. de la Vaissière, "Mani en Chine au VI siècle ", JA, 293, 2005, pp. 357-378.

3 Les autres champs d'étude représentés dans ce volume sont:

4 - Épigraphie sogdienne: N. Sims-Williams, «Towards a new edition of the Sogdian Ancient Letters: Ancient Letter 1 »; Lin Meicun, «A survey of the Turkic cemetery in Little Khonakhai » (à la frontière du Xinjiang et du Kazakhstan ; donne la photographie de la longue inscription sogdienne, dont on attend toujours le déchiffrement).

5 - Activités économiques des Sogdiens en Chine: A. Dien, "Caravans and caravan leaders in Palmyra" (dans une perspective comparatiste); M. Arakawa, "Sogdian merchants and Chinese Han merchants during the Tang dynasty »; É. Trombert, « Un vestige vivant de la présence sogdienne en Chine du Nord : le vignoble du Shanxi ».

6 - Numismatique: F. Thierry, «La monétarisation de la société türke ( $\mathrm{VI}^{\mathrm{e}}$-IX ${ }^{\mathrm{e}}$ siècle). Influence chinoise, influence sogdienne ».

7 - Sociologie et démographie sogdiennes à Turfan et Dunhuang: V. Hansen, "The impact of the Silk Road trade on a local community: The Turfan oasis, 500-800»; J.K.Skaff, "Documenting Sogdian society at Turfan in the seventh and eighth centuries: Tang dynasty census records as a window on cultural distinction and change »; Zheng Binglin, "Non-Han ethnic groups and their settlements in Dunhuang during the Late Tang and Five Dynasties».

8 - Figurations de marchands sogdiens dans les grottes bouddhiques de Kucha et de Dunhuang: Rong Xinjiang, "Sabao or Sabo: Sogdian caravan leaders in the wallpaintings in Buddhist caves»; E. Kageyama, "Sogdians in Kucha, a study from archaeological and iconographical material ».

9 - Rôle militaire des Sogdiens en Chine : É. de la Vaissière, "Čākar sogdiens en Chine "; Yu. Moribe, "Military officers of Sogdian origin from the late Tang dynasty to the period of Five Dynasties ».

10 - Religion et idéologie: P. Riboud, «Réflexions sur les pratiques religieuses désignées sous le nom de xian » (il ne s'agirait pas seulement du zoroastrisme sogdien, mais aussi de certaines pratiques du monde steppique); F. Grenet, "The self-image of the Sogdians » (principalement d'après la « Peinture aux ambassadeurs » de Samarkand et les tombeaux sogdiens de Chine ; l'art sogdien n'a en fait consacré que très peu de place à l'activité marchande).

11 - Impact sogdien sur les arts en Chine: Zhang Qingjie, "Hutengwu and Huxuanwu. Sogdian dances in the Northern, Sui and Tang dynasties »; Qi Dongfang, « The Hejiacun treasure and Sogdian culture» (argenterie); A. Sheng, "From stone to silk: Intercultural transformation of funerary furnishings among Eastern Asian peoples around 475-650 CE » (voir en particulier pp. 167-168, où l'A. propose de lier la soudaine et brève floraison de l'art funéraire sogdien en Chine du Nord entre 579 et 592 à la persécution du bouddhisme par les Zhou septentrionaux, laquelle aurait mis au chômage des sculpteurs travaillant pour les monastères bouddhiques et désormais disponibles pour les commandes des sabao sogdiens). 
INDEX

Thèmes : 3.1. Est de l'Iran

\section{AUTEURS}

FRANTZ GRENET

CNRS - EPHE - Paris 